\title{
Adjudging the Teacher Perceived Authentic Leadership, Leader- Member Exchange (LMX) Model of Management and Managerial Competence of Educational Leaders
}

\author{
Ofelia T. Posecion ${ }^{1 *} \quad$ Arnold T. Posecion ${ }^{2}$ \\ 1. University of Negros Occidental Recoletos, Bacolod City, Philippines \\ 2. Carlos Hilado Memorial State University, Bacolod City, Philippines
}

\begin{abstract}
Teacher -perceived Authentic Leadership Dexterity, Leader-Member (LMX) Management Skills and Managerial Competence of Educational Leaders in Region VI, Western Visayas, Philippines are empirically adjudged in this research work. Authentic Leadership Dexterity was investigated in terms of the authentic standards of Insight, Influence, Initiative, Impact and Integrity, the Leader-member (LMX) Management Skills in terms of Role Making, Role Taking and Routinization management aspects; and the Managerial Competence of Educational Leaders in terms of Planning, Organizing, Communicating, Controlling and Directing management functions. Significant correlations between and among the Authentic Leadership Dexterity, Leader-member (LMX) Management Skills and Managerial Competence of the Educational Leaders as perceived by the Teacher-respondents were statistically determined.The hypothesis presented was that there are no significant correlations between and among the Authentic Leadership Dexterity, Leader-member (LMX) Management Skills and Managerial Competence of the Educational Leaders. Descriptive method of research was used in this study, the data gathering tools employed were sets of questionnaires on Authentic Leadership, the Leader-member (LMX) Management Skills, and Managerial Competence. Detailed methodological instructions were embedded in the research instrument. Mean was used with its corresponding verbal interpretations for research questions 1,2, and 3, while Pearson's Product Moment Correlation Coefficient was computed as the data-analysis instrument to determine the significance of the correlation between the paired variables, and processed through the Statistical Program for Social Sciences (SPSS).Authentic Leadership of Educational Leaders, as well as their Managerial Competence, were rated as very good while their management skill based on the Leader-member (LMX) model was excellent, most specifically on Role-taking and Role making, with a significant correlation between and among manifestations of Authentic Leadership, Managerial Competence and the Leader-member (LMX) Model Management Skill of educational leaders.In conclusion, the results of this research investigation implied that the teacher perceived Authentic Leadership in terms of Insight, Influence, Initiative, Impact and Integrity, significantly correlate with their managerial skills on Planning, Communicating, Directing and Organizing, have a high positive correlation with their excellent management skills on Role-taking, Role making and Routinization. Moreover, based on the empirical data correlating the various managerial functions for future researchers to investigate the skills of educational leaders utilizing the LMX scale since as posited by experts, it can assess the degree of leaders and followers' mutual respect for each other's capabilities, involving subordinates in brainstorming and decision making activities, require a research agenda from every department that will look into collective constituents' efficacy, teacher-student relationships, re-routing frame of reference in designing pro-active successful planning with due consideration to routinization of activities; consistent monitoring of human resource activities to strengthen the trust, confidence and persistence among in-group team members, and providing innovative mentoring schemes to support teachers who are deployed in their areas of assignments . The themes correlating managerial competency and authentic leadership performance, educational management and innovation, comparing competencies in high performing and low performing institutions of learning, and competency profile of educational leaders, could be some of the research strands on leadership and management for future research undertakings.
\end{abstract}

Keywords: Educational Leaders, Teacher Perceived Authentic Leadership, Leader-member (LMX) Management Skills, Managerial Competence

DOI: $10.7176 / \mathrm{JEP} / 10-12-04$

Publication date: April $30^{\text {th }} 2019$

\section{Introduction and Related Literature}

This research endeavor aims to adjudge if there are significant relationships between and among Authentic Leadership Dexterity, Leader-member (LMX) Management Skills and Managerial Competence of Educational Leaders as perceived by the teachers.

Michael Hyatt (2018) posited that "Successful leaders understand that the path of leadership is a journey of discovery about themselves". "We are not textbooks to be read once and then put away to gather dust", "Our lives are a living testimony to change, growth, and renewed hope" These lines from Hyatt inspired the researchers 
to look into the essence of teacher_perceived Authentic Leadership, Management Skills based on LeaderMember Exchange (LMX) Model, and Managerial Competence of the Educational Leaders in Region VI, Western Visayas, Philippines.

Related readings, literature and research studies on Authentic Leadership, Managerial Competence, Leadermember (LMX) Management are presented in the foregoing paragraphs.

\section{Authentic Leadership}

Authentic Leadership is required in providing managerial leadership in the administration of schools; good management practices are specific needs of all institutions, from the smallest to the largest, vital components that hold them together and make the system work. None of these institutions could function without good managers (Koontz, 2002); managers of institutions are society's most visible leadership groups, and every major task is being performed in and through the small and large institutions that are led by managers.

Michael Hyatt (2018), described Authentic Leadership based on the following standards: (a) Insight which is sometimes referred to as the vision that usually has exclusive to the circumstances that may happen in the future. According to Michael Hyatt(2018), Leaders need wisdom and discernment for the present, and need to be able to look at complex situations, gain clarity, and determine a course of action; (b) Initiative, an attribute of an authentic leader which expects that Leaders go first, don't sit on the sidelines, nor ask others to do what they are unwilling to do themselves but instead, they lead by example, an attribute that distinguishes leaders from theoreticians and armchair quarterbacks; (c) Influence, which Hyatt(2018) pointed out that leadership is often described as an influence process, leaders influence people to do things that they might not do otherwise. (Mitch McCrimmon, 2018), pointed out also that most people who associate leadership with influence are referring to how the person in charge of others gets subordinates to work harder or do things they may not want to do; the idea is that such a leader can't dictate what people should do and, anyway, some form of persuasion or inspiration is better than intimidation or coercion. (d) Impact- Michael Hyatt posited that the measure of leadership cannot be found in the leader. It is found in the impact the leader has on his or her followers, that at the end of the day, leaders make a difference as they either instrumental in creating real and lasting change, or they're not leaders;(e ) Integrity, according to Michael Ray Hopkin, (2012), Integrity is one of the top attributes of a great leader. It is a concept of consistency of actions, values, methods, measures, principles, expectations and outcomes. It connotes a deep commitment to doing the right thing for the right reason, regardless of the circumstances. People who live with integrity are incorruptible and incapable of breaking the trust of those who have confided in them. Every human is born with a conscience and therefore the ability to know right from wrong. Moreover, according to Hopkins, choosing the right, regardless of the consequence, is the hallmark of integrity. The key that too many managers miss is "then live by them."

Moreover, Michael Hyatt believes that leadership includes at least five characteristics or marks of Authentic leadership; being an authentic leader is more than influence, Authentic leaders have Insight,

Authentic Leaders demonstrate Initiative, Authentic Leaders exert Influence, Authentic Leaders have Impact and Authentic Leaders exercise Integrity. (https://michaelhyatt.com/the-five-marks-of-authentic-leadership.html)

In the study conducted by (Duval \& Silvia, 2002; Klenke, 2007; Ladkin \& Taylor, 2010; Ricœur, 1992; Sparrowe, 2005; Toor \& Ofori, 2010) on Authentic Leadership, they posited that Self-awareness or knowledge of one's true self is a challenging topic given the plethora of theoretical perspectives that inform the topic which is somehow similar to Insights, the authors Duval, Silvia, and Lalwani (2001) further postulated that self-awareness as a comparison of object self against a standard of correctness when attention focuses on the self, finding that a person can address differences by either changing behavior to align to the standard, removal of attention away from the object self, or changing the standard. One potential intervention strategy is to identify the author's standard of correctness as it pertains to leadership and determine specific differences in behavior, although the intervention may prove difficult and challenging since there is a dearth of tools for self-reflection. Sparrowe (2005) observes that many authentic leadership perspectives focus on the inward nature of self, suggesting that leaders look inward to identify their true self. Sparrowe (2005) recommends a series of interventions for authentic leaders that seek greater self-awareness. Interventions include developing autobiographical works like journals or obituaries, identifying alternative positive variations of future narratives from other leaders through consumption of biographies, and using tools to engage others in helping identify a future narrative; such as the Center for Positive Organizational Scholarship's Reflective Best Self Exercise.

The study of Sean T. Hannah, Paul B. Lester and Gretchen R. Vogelgesang entitled, "Moral Leadership: Explicating The Moral Component of Authentic Leadership", they advanced that Authentic leadership is defined in large part by evidence of morality in the leadership influence process, that a highly developed moral leader is expected to act in concert with his or her self-concept, to achieve higher levels of agency to make the "right" and " "ethical" decisions. Moral leadership is developed through a highly developed self-concept, and supported by heightened abilities of meta-cognitive and emotional regulation. According to these authors, "these cognitive structures and abilities help leaders to activate moral solutions cross-situationally during leadership episodes, and 
further posited that a leader who is perceived by followers as morally authentic and imbued by altruism and virtuousness will be afforded greater influence and have increased positive effects on followers and organizations".

The study conducted by Clapp-Smith, Vogelgesang \& Avey (2009), yielded information that Authentic Leadership leads to trust in management and positively affects group performance measured by unit sales growth. In the same stance, Hassan \& Ahmed (2011) found that Authentic Leadership promotes subordinates' trust in the leader and contributed to work engagement

Research results of the study conducted by Laschinger, Wong \& Grau (2012) also showed that Authentic Leadership has a negative direct effect on workplace bullying and emotional exhaustion and a positive effect on job satisfaction; Peterson et al. (2012) find that authentic leadership behavior exhibited by leaders is positively related to follower job performance.

Peus et al. (2012) found that followers' satisfaction with supervisor, organizational commitment and extra effort, and perceived team effectiveness were outcomes of AL. Hmieleski, Cole, \& Baron (2012) found that shared AL has a positive indirect effect on firm performance. Leroy, Palanski \& Simons (2012) found that AL is related to follower affective commitment and work role performance. Rego et al. (2012b) find that AL predicts employees' creativity.

Rego et al. (2012c) found that AL predicts team affective commitment and team potency. Walumbwa et al. (2008) found a positive relationship between AL and supervisor-rated performance. Walumbwa et al. (2010) found that AL was positively related to supervisor rated organizational citizenship behavior and work engagement. Woolley, Casa, \& Levy (2011) reported a positive relationship between AL and followers' psychological capital, partially mediated by a positive work climate and a significant moderating effect from gender.

\section{The Leader-Member Exchange (LMX) Model of Management}

Terri A. Scandura, Melanie J. Lankau (https://doi.org/10.1016/S1048-9843(96)90043-0) discussed in their research work "Developing diverse leaders: A leader-member exchange approach", that the Leader-Member Exchange (LMX) process has been linked to the effective development of leaders, as well as outcomes for individuals and organizations such as performance and turnover.

Erdogan, Berrin \& Bauer, Talya. (2015) discussed that Leader-member exchange (LMX) theory is a relationship-based, dyadic theory of leadership. According to this theory, leadership resides in the quality of the exchange relationship developed between leaders and their followers. High-quality exchanges are characterized by trust, liking, and mutual respect, and the nature of the relationship quality has implications for job-related wellbeing and effectiveness of employees.

In Leadership-Member Exchange (LMX) Theory, informal observation of leadership behavior suggests that the leader's action is not the same towards all subordinates. The importance of potential differences in this respect is brought into sharp focus by Graen's leader-member exchange model, also known as the vertical dyad linkage theory. The theory views leadership as consisting of a number of dyadic Role Making linking the leader with a follower. The quality of the relationship is reflected by the degree of mutual trust, loyalty, support, respect, and obligation. According to the theory, leaders from different kinds of Role Making with various groups of subordinates. One group, referred to as the in-group, is favored by the leader. Members of in-group receive considerably more attention from the leader and have more access to the organizational resources. By contrast, other subordinates fall into the out-group. These individuals are disfavored by the leader. As such, they receive fewer valued resources from their leaders.

The Leader-Member Exchange Theory first emerged in the 1970s, where LMX model focuses on the relationship that develops between managers and members of their teams (Mindtools.com, 2017); effective leaders need to establish high-quality personalized Role Making with individual group members. The theory states that all Role Making between managers and subordinates go through three stages which are:(1) Role-Taking, in this phase, occurs when team members first join the group, the member joins the team and the leader evaluates his/her abilities and talents; the leader may offer opportunities to demonstrate capabilities. Managers use this time to assess new members' skills and abilities; (2) Role-Making, in which during this stage, new team members then begin to work on projects and tasks as part of the team.

In this stage, managers generally expect that new team members will work hard, be loyal and prove trustworthy as they get used to their new role. The leader and member take part in an unstructured and informal negotiation whereby a role is created for the member and the unspoken promise of benefit and power in return for dedication and loyalty, and trust building is important.

Leader-member (LMX) Management Skills include Role-taking, Role-Making, Role-taking, relationship, and Routinization to define what a successful manager's potentials should be, one must investigate the competencies that he or she possesses to determine how successful a person will be at managing others. The relationship between leaders and followers follows three stages: Role taking: When a new member joins the organization, the leader assesses the talent and abilities of the member and offers them opportunities to demonstrate their capabilities; Role making: An informal and unstructured negotiation on work-related factors takes place between the leader and the 
member. A member who is similar to the leader is more likely to succeed. A betrayal by the member at this stage may result in him being relegated to the out-group, and Routinization. Routines between team members and their managers are established by showing trust, respect, empathy, patience, and persistence.

The Leader-Member Exchange Theory(https://www.mindtools.com), Getting the Best From all Team Members, and also known as LMX or Vertical Dyad Linkage Theory, as posited by the Mindtools Content Team, "as a manager, it's not always right to treat everyone on your team in the same way", that in instances where one probably have team members that you've developed a great relationship with: you trust them, they work hard, and they've never let you down, for managers, these team members are invaluable, and managers tend to make an extra effort to send challenging projects their way.

It is also possible that there are employees or members in the team, whom managers think less well of those who may not have far-reaching career goals, less competent, and may not simply be trusted to the same extent. In this instance, these team members get everyday responsibilities and are not considered for promotions or challenging assignments. If leaders have ever stopped to analyze why certain team members are not trusted, which, rightly or wrongly, leaders may also let that distrust, or the belief that they're unreliable, influence how they relate to them, or perhaps, the leaders themselves subconsciously, withhold opportunities that might help them grow and succeed.

\section{Managerial Competence of Educational Leaders}

Managerial Competence, according to Daft, (2003) is the manager's ability to create conditions and environment that enable organizations to survive and thrive, the skill or ability of the educational leaders to handle the machinery of the school and its operations, in terms of the different management functions of planning, organizing, directing and controlling. It further involves direction, control, and operation of the institutional activities to accomplish the desired vision-mission of the institution.

McLaughlin et al. stressed that the location of authority affects which job aspects (e.g. managerial or academic) account for job satisfaction of department heads. Vroom's theory cited that employee effort will lead to performance and performance will lead to Routinization (Vroom, 1964), where Routinization may be either positive or negative. The more positive the reward, the more likely the employee will be highly motivated. Conversely, the more negative the reward the less likely the employee will be motivated.

Educational Leaders do their Organizing function as guided by the theory of Daft (2002), who postulated that organizing is the management function that is concerned with assigning tasks, grouping tasks into departments, and allocating resources to departments. The Planning Management function of educational leaders are concerned with defining goals for future organizational performance and deciding on the tasks and resource use needed to attain them. According to Daft, (2002), Planning encompasses defining an organization's goals and developing a comprehensive hierarchy of plans to integrate and coordinate activities. There are acknowledged most effective ways in which leaders solve problems (https://www.forbes.com/sites/glennllopis/2013/11/04). Problems we are all faced with in our work and life needs time to solve each one without dealing with some adversity along the way since problems keep mounting so fast that we find ourselves taking short-cuts to temporarily alleviate the tension points - so we can move onto the next problem. In the process, we fail to solve the core of each problem we are dealt; thus, we continuously get caught in the trap of a never-ending cycle that makes it difficult to find any real resolutions. (https://www.forbes.com/sites/glennllopis/2013/11/04).Problem-solving is the essence of what leaders exist to do, as leaders, the goal is to minimize the occurrence of problems - which means we must be courageous enough to tackle them head-on before circumstances force our hand.

Karl Popper, one of the most influential 20th-century philosophers of science, once eloquently stated, "All life is problem-solving.", leaders who lack this wisdom approach problem with linear vision - thus only seeing the problem that lies directly in front of them and blocking the possibilities that lie within the problem.

Glenn Llopis (2013), mentioned that whether you are a leader for a large corporation or a small business owner, there are four most effective ways to solve problems: (1) Transparent Communication, problem-solving requires transparent communication where everyone's concerns and points of view are freely expressed; a leader must trust herself and her intuition enough to challenge the team until accountability can be fairly enforced and a solution can be reached; (2) Break Down Silos, in which Transparent communication requires you to break down silos and enable a boundary-less organization whose culture is focused on the betterment of a healthier whole. The third way is (3) Open-minded People, breaking down silos and communication barriers requires people to be openminded. In the end, problem-solving is about people working together to make the organization and the people it serves better. Therefore, if you are stuck working with people that are closed-minded, effective problem solving becomes a long and winding road of misery, Open-minded people see beyond the obvious details before them and view risk as their best friend. Close-minded employees turn things around to make it more about themselves and less about what is required to convert a problem into a new opportunity; (4) A Solid Foundational Strategy, without a strategy, change is merely substitution, not evolution. A solid strategy must be implemented in order to solve any problem. Many leaders attempt to dissect a problem rather than identify the strategy for change that lies within 
the problem itself. Effective leaders that are comfortable with problem-solving always know how to gather the right people, resources, budget and knowledge from past experiences. They inspire people to lift their game by making the problem-solving process highly collaborative; for them, it's an opportunity to bring people closer together.

Glenn Llopis (2013) further pointed out that effective leaders connect the dots and map-out a realistic plan of action in advance. They have a strategy that serves as the foundation for how the problem will be approached and managed and they can anticipate the unexpected and utilize the strengths of their people to assure the strategy leads to a sustainable solution. Problem-solving is the greatest enabler for growth and opportunity, failure serves as the greatest lesson in business and in life.

Chye et. al. (2010) found out that managerially competent managers are good planners, organizers, administrators, and communicators who can enhance the performance of their organizations, whereas innovatively competent managers are designers, forward thinkers, leaders, and inspirer capable for creating better organizations. They also emphasized that managerial competencies are the business functional skills that have been playing an increasingly important role in the development of small and medium business firms.

The study of Hefferman and Flood (2000) has also revealed that organizational characteristics such as company size and length of time in operations have a great impact on the adoption of the competencies. They found that the organizations having sophisticated and well-organized practices are most likely to use competencies and the organizations which are performing well are more likely to have competencies framework.

Management performance is the extent and quality of managers' contribution to realizing the objectives of the organization (Shirazi and Mortazavi, 2009), a competency is considered as a measurable characteristic of a person that is related to effective performance in a specific job, organization or culture. These characteristics are defined in terms of behavior. Cockerill (1989) suggested that management performance is related to managers themselves than to their positions and authority within the organizations. Hence, the performance of the managers depends upon the experience and the competencies they bring to their jobs. Competencies are defined as the cognitive (e.g. skills and knowledge), affective (e.g. values and attitude), behavioral and motivational characteristics and dispositions of a person to perform well in a specific situation.

(Boyatzis, 1982). Finn (1993) argued that the performance of a manager (output competencies) is influenced by their job-related knowledge and experience (input competencies), and personality characteristics (process competencies). Maximum performance is believed to occur when the person's capability or talent is consistent with the needs of the job demands and the organizational environment (Boyatzis, 1982). Abraham et. al. (2001) found that the set of managerial competencies that describe successful managers. But these organizations are not paying due concern to these competencies in their performance appraisal system. They recommended that to be a high-performance organization, an organization should managerial competencies and incorporate them into the performance appraisal system.

Smart (1998) listed 50 critical competencies of top managers which primarily include intelligence, analytical skills, strategic skills, judgment and decision making, risk taking, excellence, team player, communications, assertiveness, ambition, adaptability, creativity, vision, and balance in life. These were enhanced in the study conducted by Ramo et. al. (2009) who found out that both social and emotional competencies and personality traits are the valuable predictor of job performance and also stressed that competencies are a more powerful predictor of performance as compared to global personality traits. The use of competencies serves to enhance an organization's performance and hence a competitive advantage.

(Lawler, 1994). Business case studies have shown many benefits associated with competency usage including increased employee productivity, reduced training costs, and reduced staff turnover (Homer, 2001).

(Northouse, 2013; Yukl, 2011) posited that Leadership is the process of influencing a group of individuals to achieve shared objectives (Northouse, 2013; Yukl, 2011) and that the primary function of leadership is to produce change and movement, while the primary function of management is to provide order and consistency to organizations (Northouse, 2013), while Kellerman, (2012) likewise pointed out that as both leadership and management are processes, anybody can execute leadership or managerial functions at different times, and "leaders cannot be called as leaders simply by virtue of the position they hold in organizations."

The above cited related literature, research works and other pertinent undertakings provided directions to the present research endeavor which purported to adjudge the dexterity, competence, and skills of educational leaders and the implementation of management and leadership functions in their respective institutions as perceived by their teacher-constituents.

It also delved into the possible correlation between and among the teacher-perceived Authentic Leadership Dexterity in terms of the authentic standards of Insight, Influence, Initiative, Impact, and Integrity, their skills anchored on the Leader-member (LMX) Model in its three stages, namely: Role Making, Role Taking and Routinization, and the Planning, Organizing, Communicating, Controlling and Directing Managerial Competencies of the educational leaders. The schematic diagram illustrates the conceptual framework of this research undertaking. 




The Schematic Diagram of the Research Work

\section{The Research Questions}

The following research questions were addressed in this research endeavor:

RQ1. How is Authentic Leadership Dexterity of Educational Leaders in terms of the authentic standards of Insight, Influence, Initiative, Impact, and Integrity perceived by teachers?

RQ2. Is the Management Skill of Educational Leaders based on the Leader-member (LMX) Model in Role Making, Role Taking and Routinization management aspects commendable?

RQ3. How do teachers perceive the Managerial Competence of Educational Leaders in terms of Planning, Organizing, Communicating, Controlling and Directing management functions?

RQ4. Are there significant relationships between and among the teacher-perceived Authentic Leadership Dexterity, Leader-member (LMX) Management Skills and Managerial Competence of the Educational Leaders?

\section{Hypothesis}

HQ. There are no significant relationships between and among the Authentic Leadership Dexterity, Leadermember (LMX) Management Skills and Managerial Competence of the Educational Leaders as perceived by the teacher-respondents.

\section{Research Method}

This research work used a quantitative research method which is a means for testing objective theories by examining the relationship among variables (Polit and Hungler 2013; Moxham 2012).

The variables that were investigated were the Teacher Perceived Authentic Leadership Dexterity, LeaderMember (LMX) Management Skills and Managerial Competence that included dependent variables which were hypothesized to be possibly correlated or may depend or be caused by another variable) or Independent variable (the variable that is believed to be the cause or influence, as pointed out by (Wong 2014; Polit and Hungler 2013). The researchers employed descriptive and correlational methods, which, as posited by Borbasi and Jackson, ( 2012; Burns and Grove 2009), a descriptive research is the accurate portrayal of the characteristics of individuals, situations, or groups and the frequency with which certain phenomena occur using statistics to describe and summarize the data (Polit and Hungler 2013), while correlational research explores the interrelationship amongst variables of interest without any active intervention on the part of the researcher (Polit and Hungler 2013).

The descriptive-correlational method of research was deemed the appropriate method in determining the correlation of the variables among the obtained results from the teacher respondents.

The data gathering research tools employed by the researchers were sets of questionnaires on Teacher Perceived Authentic Leadership dexterity, the Managerial Skills of Educational leaders based on the LMX Model, and their Managerial competence, with detailed methodological instructions embedded in the research instrument. The questionnaires were conducted to a sample of teachers who were randomly chosen from the population of teachers of schools within Western Visayas in the Philippines.

For data analysis, mean was utilized to answer research questions 1,2 , and 3, and interpreted based on the following scale: 


\begin{tabular}{|l|l|}
\hline Mean Score & Verbal Interpretation \\
\hline $4.21-5$ & Excellent \\
\hline $3.41-4.2$ & Very Good \\
\hline $2.61-3.4$ & Good \\
\hline $1.81-2.6$ & Fair \\
\hline $1-1.8$ & Poor \\
\hline
\end{tabular}

The correlation between and among the Authentic Leadership Dexterity, the LMX Model of Management, and their Managerial Competence, were calculated to determine if there are significant relationships between and among the identified variables.

Pearson Product Moment Correlation Coefficient was the statistical tool used and the computation of the test statistics was processed through the Statistical Program for Social Sciences (SPSS) to determine the significance of relationship interpreted based on the level of significance set to lower than the assumed p level of 0.05.

The Pearson correlation was used to determine whether a statistically significant linear relationship exists between the paired continuous variables: Authentic leadership vs LMX management skills, Authentic leadership vs Managerial competence, and LMX management skills vs Managerial competence.

The degree of linear correlation was interpreted with the range of values for the Pearson Product Moment Correlation Coefficient as shown in the reference table, below (General Statistics Made Simple for Filipinos, (Nocon et al.), which ranges from -1.0 to +1.0 -- indicating perfect negative and positive relationships, as reflected in the scale below.

\begin{tabular}{|l|l|}
\hline Range of Values & Interpretation \\
\hline 1.0 to -1.00 & Perfect Positive/Negative Correlation \\
\hline 0.90 to $0.99(-0.90$ to -0.99$)$ & Very High Positive (Negative) Correlation \\
\hline 0.70 to $0.89(-0.70$ to -0.89$)$ & High Positive (Negative) Correlation \\
\hline 0.50 to $0.69(-0.50$ to -0.69$)$ & Moderate Positive (Negative) Correlation \\
\hline 0.30 to $0.49(-0.30$ to -0.49$)$ & Low Positive (Negative) Correlation \\
\hline 0.00 to $0.29(0.00$ to -0.29 & Very Low Positive (Negative) Correlation \\
\hline
\end{tabular}

\section{Results of the Study}

The combined mean scores and verbal interpretations of Authentic Leadership Dexterity, Leader-Member Management Skill (LMX) and Managerial Competence of the Educational Leaders is shown in Table 1.

Table 1: Mean scores for each of the variables

\begin{tabular}{|l|c|c|l|}
\hline \multicolumn{1}{|c|}{ Variables } & Mean & Standard Deviation & Verbal Interpretation \\
\hline Authentic Leadership Dexterity & 3.87 & 0.912 & Very Good \\
\hline Leader-Member Management Skill & 4.56 & 0.864 & Excellent \\
\hline Managerial Competence & 3.84 & 0.932 & Very Good \\
\hline
\end{tabular}

As seen in the table, the mean scores of the Authentic Leadership Dexterity is 3.87, with a standard deviation of 0.912 and interpreted as Very Good. This result may imply that the teachers perceived a higher than mediocre authentic leadership of their educational leaders.

On the other hand, the skill of the educational leaders based on the Leader-Member Management Model is 4.56, with a standard deviation of 0.864 , and verbally interpreted as excellent. In this aspect, the perception of teachers on the managerial skill of the educational leader is exceptionally high, and may imply that based on the LMX model, their educational leaders have admirable performance as leaders.

The Managerial Competence with a mean score of 3.84, and a standard deviation of 0.932; was interpreted as Very Good. This result implies that the teachers see their educational leaders to have possessed a higher than average management competence in doing their functions on planning, communicating, directing and controlling. The individual indicators and components of each variable are reflected in Tables 2,3, and 4.

RQ1. The mean scores for the Teacher Perceived Authentic Leadership of Educational Leaders in terms of Insight, Influence, Initiative, Impact and Integrity is shown in Table 2. 
Table 2: Teacher Perceived Authentic Leadership Dexterity

\begin{tabular}{|l|l|l|}
\hline Components of Authentic leadership & Mean & Verbal Interpretation \\
\hline Insight & 4.23 & Excellent \\
\hline Influence & 3.42 & Very Good \\
\hline Initiative & 3.48 & Very Good \\
\hline Impact & 3.97 & Very Good \\
\hline Integrity & 4.22 & Excellent \\
\hline Over-all mean & $\mathbf{3 . 8 7}$ & Very Good \\
\hline
\end{tabular}

As reflected in the table, the mean score describing the Authentic leadership dexterity of educational leaders in terms of Insight is 4.23, which is interpreted as excellent. This result may imply that the perception of the teachers about their leaders is that they have an excellent vision that usually are exclusive to the circumstances that may happen in the future. According to Michael Hyatt (2018), leaders need wisdom and discernment for the present and need to be able to look at complex situations, gain clarity, and determine a course of action. In terms of their dexterity in their management practices manifesting Initiative, the mean score 3.48, which is interpreted as very good, an attribute of an authentic leader which expects that Leaders go first, not just sitting on sidelines, nor ask others to do what they are unwilling to do themselves but instead, led by example. The teachers' perception looked into a very good attribute of leaders that distinguishes leaders from theoreticians and armchair quarterbacks, terms also posited by Michael Hyatt (2018). The Influence aspect of authentic Leadership yielded a mean score of 3.42 , very good; this result may mean that the educational leaders use an influence process, leaders influence people to do things that they might not do otherwise. (Mitch McCrimmon, 2018), these may also mean that most of the subjects of the study associate leadership with influence, and are referring to how the person in charge of others gets subordinates to work harder or do things they may not want to do.

This result is supported in the postulate of Michael Hyatt showed that the measure of leadership cannot be found in the leader but found in the impact the leader has on his or her followers. As seen by the constituents, the educational leaders looked into the Impact, the aspect of authentic leadership as very good, from the obtained mean score of 3.97. The constituents believe that to a very good extent, leaders make a difference as they either instrumental in creating real and lasting change.

The mean score of 4.22 was rated for the Integrity aspect of authentic leadership. This result is very noteworthy considering that, according to Michael Ray Hopkin, (2012), Integrity is one of the top attributes of a great leader. It is a concept of consistency of actions, values, methods, measures, principles, expectations and outcomes. It connotes a deep commitment to doing the right thing for the right reason, regardless of the circumstances. If the educational leaders live with integrity, they will be incorruptible and incapable of breaking the trust of those who have confided in them. The Over-all mean score is 3.87, which consequently mean that the Authentic leadership of the educational leaders is Very Good.

RQ.2. The Managerial Competence of Educational Leaders in terms of Communicating, Planning, Organizing, and Directing management functions.

Table 2: The Managerial Competence of the Educational Leaders

\begin{tabular}{|l|l|l|}
\hline Management Functions & Mean & Verbal Interpretation \\
\hline Communicating & 3.85 & Very Good \\
\hline Planning & 4.29 & Excellent \\
\hline Organizing & 3.78 & Very Good \\
\hline Directing & 3.52 & Very Good \\
\hline Total & $\mathbf{3 . 8 4}$ & Very Good \\
\hline
\end{tabular}

Table 2 presented the Managerial Competence of the Educational Leaders with Administrative Functions in the Communicating, Planning, Organizing and Directing, for Communicating, the Educational Leaders rated themselves as Very Good with an $(\mathrm{M}=3.85$.

In terms of Organizing, the result was interpreted as Very Good $(\mathrm{M}=3.78)$, around Directing, the rating was interpreted likewise as Very Good, the highest rating of Excellent was in Planning $(M=4.29$.) This result showed that majority of the Educational Leaders with executive positions are excellent in their Planning skills, as they prepare for all the areas of responsibility in their college or departments.

The overall rating for the Managerial Competence of the Educational Leaders in all four areas combined, was Very Good, with the mean score of 3.84 with the verbal interpretation of Very Good.

According to De Cenzo and Robbins (2005), organizing is determining what tasks are to be done, who is to do them, how the tasks are to be grouped, who reports to whom, and where decisions are to be made. The focus is on division, coordination, and Role Making of tasks and flow of information within the organization. Managers distribute responsibility and authority to the jobholders in this function of management. (Ervin,2004)

Educational Leaders should, therefore, focus on the distribution of authority and clarify the functions expected 
of each member of the organization. An organizational chart will help very much in defining the function of each one. In terms of Directing, the rating for the Educational Leaders is very good, while in Communicating, the Teacher Perceived Authentic Leadership of the Educational Leaders is also very good $(\mathrm{M}=3.52)$. While it is true that the Educational Leaders, were rated as very well most of the time, there is still room for improvement on the part of the Educational Leaders so that they will be perceived as Excellent by their subordinates. Perhaps, there is a need for them to closely communicate frequently with their subordinates. They should remember that failure to communicate with their subordinates will result in misunderstanding. Mackenzie (2002) stated that investing adequate time to give clear instructions brings about more effective communication, better performance and greater savings in time, money and effort.

RQ.3. The Leader-member (LMX) Management Skills of Educational Leaders in terms of Role Making, Role Taking, Routinization functions, through the mean as the statistical tool.

Table 3. The Leader-member (LMX) Management Skills of the Educational Leaders

\begin{tabular}{|l|l|l|}
\hline Aspects of LMX Management Model & Mean & Verbal Interpretation \\
\hline Role taking & 4.65 & Excellent \\
\hline Role making & 4.58 & Excellent \\
\hline Routinization & 4.19 & Very Good \\
\hline Total & $\mathbf{4 . 4 7}$ & Excellent \\
\hline
\end{tabular}

As shown in the table, the management skills of the educational leaders who are respondents of this study showed an excellent skill on Role-taking, yielded by the mean score of 4.65. This result may imply that majority of the educational leaders, as perceived by their teacher-constituents perceived, that when a new join the organization, the leader assesses the talent and abilities of the member and offers them opportunities to demonstrate their capabilities.

On the other hand, the perception of the constituents on the managerial skill of the educational leaders in terms of Role -making is 4.25, which is also interpreted to be verbally interpreted as Excellent. It is only in Routinization where the mean score is 4.19 which, though lower than their Role making skill yielded a total mean score of 4.47, which is verbally interpreted as Excellent, which may an outstanding performance.

These results are consonant with the concepts of the proponents of the LMX theory model of management, for constituents to perceive that educational leaders are skilled in Role making and Role-taking, where there is an informal and unstructured negotiation on work-related factors takes place between the leader and the member, and a member who is similar to the leader is more likely to succeed, with the possibility that a betrayal by the member at this stage may result in him being relegated to the out-group. The result on the skills in terms of Routinization is very good, though lower.

This might also mean that during this last phase, routines between team members and their managers are established, in-group team members work hard to maintain the good opinion of their managers, by showing trust, respect, empathy, patience, and persistence, as manifested by the educational leaders. These results may imply that during this last phase, routines between team members and their managers are established, in-group team members work hard to maintain the good opinion of their managers, by showing trust, respect, empathy, patience, and persistence, as manifested by the educational leaders.

RQ.4. The significance of correlations between and among Teacher Perceived Authentic Leadership and Managerial Competence of Educational Leaders in Western Visayas, Philippines.

Table 4. Correlational Data between and among Authentic Leadership Dexterity, Leader-member (LMX) Management Skills and Managerial Competence of the Educational Leaders

\begin{tabular}{|l|c|c|l|l|}
\hline PAIRED VARIABLES & $\mathbf{r}$ & $\begin{array}{c}\text { p- } \\
\text { value }\end{array}$ & Interpretation & $\begin{array}{c}\text { Status of } \\
\text { the hypothesis }\end{array}$ \\
\hline $\begin{array}{l}\text { Authentic Leadership Dexterity vs. Leader-member } \\
\text { (LMX) Management Skills }\end{array}$ & 0.87 & .032 & Significant & Rejected \\
\hline Authentic Leadership vs. Managerial Competence & .90 & .000 & Significant & Rejected \\
\hline $\begin{array}{l}\text { Leader-member (LMX) Management Skills vs. } \\
\text { Managerial Competence }\end{array}$ & .025 & Significant & Rejected \\
\hline
\end{tabular}

*Significant at 0.05 level

Table 4, shows the computed values of Pearson's r when Teacher Perceived Authentic Leadership of the Educational Leaders were correlated with Managerial Competence with an r-value of 0.87 which was interpreted as a high positive correlation. This result implies that the teachers' perception of the authentic leadership of educational leaders as they act in a real, genuine and sincere way that is true to who they are as individuals; manifest through their practices to inspire trust, loyalty and strong performances from employees.(https://searchcio.techtarget.com/definition/authentic-leadership); and that when associated with their 
Leader-member (LMX) Management Skills, it has a positive correlation to the effective development of the educational leaders, as well as outcomes for individuals and organizations in terms of work performance and turnover. The paired variables yielded a p-value of 0.032 , which is significant at 0.05 , thus the hypothesis is rejected.

From the same table, when Authentic Leadership Dexterity was correlated with Managerial Competence, an r-value yielded was 0.90 which was interpreted as a very high positive correlation; such result implies that their being authentic leaders who are positive people with truthful self-concepts who promote openness have a very high positive correlation with the skills, motives, and attitudes that are necessary to the job of the educational leaders, including their communication skills, problem-solving, customer focus and the ability to work within a team. From the same the table, the obtained p-value between Authentic Leadership Dexterity and Leader-member (LMX) Management Skills, was .032 which is interpreted as significant, the hypothesis is rejected,

The computed $r$-value between Managerial Competence and Leader-member (LMX) Management Skills was 0.79 which was interpreted as a high correlation, with a p-value of 0.025 which was interpreted as significant at 0.05 level of significance, thus the hypothesis is rejected. This result may imply that these competencies of educational leaders that are embedded in the planning, delegating, communicating and directing functions of managing people, influence their competence as good planners, organizers, administrators, and communicators that can enhance the performance of their organizations, and has a high positive correlation with their innovations as designers, forward thinkers, leaders, and inspirer who are capable for creating better organizations. This result may imply that the competencies of the educational leaders in terms of their relationship-based, dyadic theory of leadership manifest the quality of the exchange relationship developed between leaders and their followers.

Thus, for research question 4, the hypothesis which states that the Teacher-Perceived Authentic Leadership Dexterity and Leader-member (LMX) Management Skills of Educational Leaders do not significantly influence their Managerial Competence is rejected because based on the interpretation of the data gathered, they do affect or influence each of the paired variables.

\section{Summary and Conclusions}

\section{A. Conclusions}

Based on the results of this research endeavor, the Leader-Member Exchange Theory management skills were perceived by teachers that as their team members in its typical ways of going through three phases in their relationship with their educational leader: Role-Taking, Role-Making, and Routinization. The skills were identified and have validated their perceptions about what they might have on people of their team; excellent for both Role-taking and Role making, Very Good on Routinization.

In this aspect, teachers who are constituents of the educational leaders in Western Visayas perceived the highquality exchanges between leaders and teachers which are characterized by trust, liking, and mutual respect, and the nature of the relationship quality has implications for job-related well-being and effectiveness of the teachers in their respective schools and learning environments.

Consequently, the teacher-perceived Authentic Leadership Dexterity and Leader-member (LMX) Management Skills of Educational Leaders, when paired with one another, have a very high positive correlation with one another, and significantly influence their Managerial Competence. When pairing was done between and among the (3) three variables, the quantitative interpretation was almost the same, with a High Positive correlation between the paired variables; the higher the teacher perceived Authentic Leadership of Educational Leaders, the higher is their Managerial Competence, the higher the Managerial Competence, also highly influences the Leadermember (LMX) Management Skills of Educational Leaders of educational institutions in Western Visayas.

Moreover, the findings based on the research questions specifically on leadership based on the LMX model, implied some definite assumptions that leaders support the teachers who are in the in-group; and consequently may even go to the extent of inflating their ratings on poor performance as well; a kind of a treatment which is not extended to members of the out-group with whom supervisors may not share the same outlook. There is a possibility of favoritism that the in-group members receive from their supervisors, but which may imply, that because of the apparent support from their educational leader, they may perform well in their work assignments and develop positive attitude towards their teaching career in comparison to the teachers who are members of the out-group.

In manifesting high support to the teachers in the in-group, educational leaders implicitly influence the job satisfaction of in-group members for them to perform effectively on their jobs and succeed since they tend to receive more mentoring from their immediate superiors to be more productive in their careers.

Conclusively, the results of this research investigation implied that the teacher perceived Authentic Leadership in terms of Insight, Influence, Initiative, Impact and Integrity, significantly correlate with their managerial skills on planning, communicating, directing and organizing, and likewise have a high positive correlation with their excellent management skills on Role-taking, Role making and Routinization based on the Leader-member (LMX) model. 


\section{B. Recommendations}

The following recommendations are presented, with suggestions on themes and related management and leadership strands for future research directions which may be pursued by educational institutions:

1.Involving subordinates to participate in brainstorming ideas and decision makings, because a collective teacher efficacy which is highly influenced by authentic leadership, creates the greatest impact on student achievement, and may also be positively correlated to factors higher than teacher-student relationships, community environment, or alumni and parental involvement.

2. Re-routing frame of reference on Leader-Member Exchange Theory to be used by professionals and practitioners for them to be aware of how one perceives the members of their own team; identify their Out-Group, and the reasons why there are employees who resigned from the institution. An organized Exit protocol must be reviewed for future reference.

3. Consistent and periodic monitoring of human resource activities be done to strengthen the trust, confidence, and persistence among in-group team members as inherent in the Routinization phase of the LMX management model. Further research undertaking may be conducted on this phase.

4. Monitoring of indicators present in the work environment to check on quality of relationships between team members with their leaders since team members with higher morale is more productive than those with lower morale, an aspect that can be beneficial to the leaders and the organization.

5. Leaders must practice management by walking around, being visible to employees so immediate help on projects or tasks can be provided, applying the "walk the talk" adage.

6. Fairness in providing Training, Development and Advancement Opportunities, utilizing the LeaderMember Exchange Theory that alerts leaders to the preferences which they might unconsciously - and sometimes unfairly manifest to some team members.

7. Designing a mentoring or coaching relationship program with Out-Group team members, and task allocation strategies to make sure that the right task is assigned to the right person, with training sessions on setting goals for the team;

8. Enhancing Teacher efficacy and managerial competencies that lead to a strengthened classroom management skill to develop a stronghold of teachers who believe in their own ability to empower themselves, their colleagues and students to succeed.

9. Designing a proactive succession planning scheme that considers internal people to fill-in business leadership positions in the institution, for continuity of leadership.

10. Enriching the research agenda on themes correlating managerial competency and authentic leadership performance, educational management and innovation, comparing competencies in high performing and low performing institutions of learning, and competency profile of educational leaders, could be some of the strands on leadership and management for future researches.

\section{Acknowledgements}

The researchers acknowledge the support and the much-appreciated assistance of the school administrators from the government and private institutions in Western Visayas who gave permission to conduct this research and allowed their teachers to be the respondents of this research undertaking.

Acknowledgements are also accorded to those who have extended their services to facilitate the gathering of the questionnaires, and other pertinent support to the researchers in making the conduct of this study, a reality.

\section{References}

Abraham, S.E., Kams, L.A., Shaw, K. and Mena, M.A. (2001), "Managerial competencies and the managerial performance appraisal process", Journal of Management Development, Vol. 20, No 10, pp. 842-852.

Barber, C.S. and Tietye, B.C. (2004), "Competency requirements for managerial development in manufacturing, assembly, and/or material processing functions”, Journal of Management Development, Vol. 23, No. 6, pp. 596-607.

Boyatzis, R.E. and Saatcioglu, A. (2008), “A twenty-year view of trying to develop emotional, social and cognitive intelligence competencies in graduate management education”, Journal of Management Development, Vol. 27, No. 1, pp. 92-108.

Blais, Simon, February 24, 2016, "Overview of the leader member exchange theory"

Blake, Jesse, Penn. State.edu, December 5, 2014, "Leadership member theory "Boston: McGraw-Hill Higher Education. (Original work published 2000)

Boyatzis, R.E., (2008), “Competencies in the 21st century”, Journal of Management Development, Vol. 27, No. 1, pp. 5-12.

Birdir, K. \& Pearson, T. (2000). Research Chefs' Competencies: A Delphi Approach. International Journal of Contemporary Hospitality Management, 12(3), 205-209. http://dx.doi.org/10.110 8/09596110010309989

Boyatzis, R. E. (1982). The Competent Manager: A Model for Effective Performance. New York: John Villey \& 
Sons. Boyatzis, R. E. (2008). Competencies in the 21st Century. Journal of Management Development, 27 (1), 5-12. http://dx.doi.org/10.1108/02621710810840730

Burgoyne, J. (1989). Creating the Managerial Portfolio: Building on Competency Approaches to Management Development. Management Education and Development, 20 (1), 5-1.

Cheng, M., Dainty, A.R, and Moore, D.R. (2003), "The differing faces of managerial competency in Britain and America", Journal of Management Development, Vol. 22, No. 6, pp. 527-37.

Chye L., Tat H., Osman M., and Rosli A. (2010), “Are managerial competencies a blessing to the performance of innovative SMEs in Malaysia?” International Journal of Economics and Management, Vol. 4, No. 1, pp. 12036.

Cockerill, T. (1989), "The kinds of competence for rapid change”, Personnel Management, Vol. 21, No. 9, pp 5256.

Comutto, A. and Gerli, F. (2004), “An integrated competency-based approach to management education: an Italian MBA case study", International Journal of Training and Development, Vol. 8, No. 4, pp. 20-257.

De Bello, T. C. (1990). Comparison of eleven major Leader-member (LMX) Management Skills styles models: Variables, appropriate populations, validity of instrumentation, and the research behind them. Journal of Reading, Writing, and Learning Disabilities International with attention to psychometric standards, 6(3), 203-222. Ottawa, Ontario: Canadian College of Diverse academic programs Executives.

Dunn, R., \& Dunn, K. (1993). Teaching secondary students through their individual managerial competence: Practical approaches for grades 7-12. Boston: Allyn \& Bacon.

Educational Research: Competencies for Analysis and Applications, 7th Edition L. R. Gay, Peter W. Airasian (2003) |Pearson

Erdogan, Berrin \& Bauer, Talya. (2015). Leader-Member Exchange Theory. International Encyclopedia of the Social \& Behavioral Sciences. 10.1016/B978-0-08-097086-8.22010-2.

Fred Luthans, Carolyn M. Youssef(2007) Emerging Positive Organizational Behavior, Journal of Management, Volume 33 Issue 3, June 2007

Northouse, Peter G. (2012-02-02). Leadership: Theory and Practice (p. 164). SAGE Publications.

Harris, K. J., Wheeler, A. R., \& Kacmar, K. M. (2009). Leader-member exchange and empowerment: Direct and interactive effects on job satisfaction, turnover intentions, and performance. Leadership Quarterly, 20, 371382.

Graen, G. B., \& Uhl-Bien, M. (1995). Relationship-based approach to leadership: Development of leader-member exchange (LMX) theory of leadership over 25 years: Applying a multi-level, multi-domain perspective. Leadership Quarterly, 6(2), 219- 247.

Northouse, P. G. (2013). Leadership: theory and practice. New Delhi: Sage.

Peterson, S. J., Walumbwa, F. O., Avolio, B. J., \& Hannah, S. T. (2012). The relationship between authentic leadership and follower job performance: The mediating role of follower positivity in extreme contexts. The Leadership Quarterly, 23, 502-516.

Peus, C., Wesche, J. S., Streicher, B., Braun, S., \& Frey, D. (2012). Authentic leadership: An empirical test of its antecedents, consequences and mediating mechanisms. Journal of Business Ethics, 107, 331-348.

Rego, A., Sousa, F., Marques, C., \& e Cunha, M. P. (2012a). Authentic leadership promoting employees' psychological capital and creativity. Journal of Business Research, 65, 429-437.

Rego, A., Sousa, F., Marques, C., \& e Cunha, M. P. (2012b). Hope and positive affect mediating the authentic leadership and creativity relationship. Journal of Business Research, http://dx.doi.org/10.1016/j.jbusres.2012.10.003

Rego, A., Vitoria, A., Magalhaes, A., Ribeiro, N., \& e Cunha, M. P. (2012c). Are authentic leaders associated with more virtuous, committed and potent teams? The Leadership Quarterly, http://dx.doi.org/10.1016/j.leaqua.2012.08.002

Walumbwa, F. O., Avolio, B. J., Gardner, W. L., Wernsing, T. S., \& Peterson, S. J. (2008). Authentic leadership: Development and validation of a theory-based measure. Journal of Management, 34(1),

Walumbwa, F. O., Luthans, F., Avey, J. B., \& Okey, A. (2011). Authentically leading groups: The mediating role of collective psychological capital and trust. Journal of Organizational Behavior

Walumbwa, F. O., Wang, P., Wamg, H., Schaubroeck, J., \& Avolio, B. J. (2010). Psychological processes linking authentic leadership to follower behaviors. The Leadership Quarterly,21, 901-914.

Williams, L. J., Hartman, N., \& Cavazotte, F. (2010). Method variance and marker variables: A review and comprehensive marker technique, Organisational Research Methods, 13(3), 477-514.

Yukl, G. (2011). Leadership in organizations. New Delhi: Dorling Kindersley (India). 


\section{ELECTRONIC SOURCES}

www.western.edu/hr/Instructions.pdf

Teacher Perceived Authentic Leadership review - Fonteyn

https://michaelhyatt.com/the-five-marks-of-authentic-leadership/

http://www.practical-management.com/Leadership-Development/Leader-Member-Exchange.html

https:/www.forbes.com/sites/glennllopis/2013/11/04/the-4-most-effective-ways-leaders-solveproblems/\#6e530bc04f97

https://sites.psu.edu/leadership/2014/12/05/leadership-member-exchange/

https://www.stratcoltd.com/leader-member-exchange.html

https://www.mindtools.com/pages/article/leader-member-exchange.htm 